\title{
The Commercial Profitability of Growing Hybrid Eucalyptus Clones in The Coast Province, Kenya
}

\author{
Balozi Bekuta Kirongo ${ }^{* 1}$, Kingiri Senelwa ${ }^{1}$, Kimani G K ${ }^{2}$, Imo Moses ${ }^{1}$, Onkware Augustino ${ }^{1}$, Lazane Etiégni ${ }^{1}$ \\ ${ }^{1}$ Department of Forestry and Wood Science, School of Natural Resource Management, The University of Eldoret, \\ PO Box 1125, Eldoret, Kenya \\ ${ }^{2}$ Kenya Forestry Research Institute, PO Box 20412, Nairobi
}

Received November 9, 2013/Accepted April 9, 2014

\begin{abstract}
Due to the current high demand for timber, fuelwood, and building poles and the realization that tree growing may pay dividends in the short and long term, many farmers are planting trees on their farms. Farmers are increasingly planting eucalyptus partly due to the fast growth rates of the hybrid clones as well as the opportunity to earn money within a short time. In this paper we report on the profitability of growing eucalyptus hybrid clones in the coastal region, Kenya. Tree growth and cost data was sourced from farmers in Malindi, Kilifi, and Msambweni. Market information was sourced from hardwares in North and South Coast while tree growth models were used to provide average tree sizes at various ages. Results showed that a farmer could make a net income of upto Kshs.500,000.00 (USD6,250) in 5 years. Farmers in the South Coast (Kwale and Msambweni) spent more on transport than their counterparts in the North Coast (near Gede-KEFRI). This, added to the fact that trees in the South Coast (Msambweni) grew less compared to those in North Coast meant that farmers in the south made less profits.
\end{abstract}

Keywords: profitability, eucalyptus on-farm tree growing, renewable energy, afforestation

*Correspondence author, email:balozibk@hotmail.com,tel: +254-7338057

\section{Introduction}

Global concerns for renewable energy sources, especially in light of the ever increasing possibility of depletion of fossil energy sources and the negative effect combustion of fossil fuels has on the environment (e.g. green house gas emissions) have led to many countries resorting to massive afforestation and reforestation drives. While in many countries in the world the emphasis on afforestation and reforestation has been precipitated by economic gains and wood selfsufficiency, in most less developed countries increased tree planting drives by governments, non-governmental agencies and rural farmers has largely been due to increased cost of living and the unassailable prices of fossil fuels for cooking and heating (Kingiri et al. 2008c). Rural livelihoods have been decimated and prices of basic commodities have skyrocketed. Meanwhile changing weather patterns, and related phenomena blamed on unsustainable use of natural resources especially forest depletion (conversion to agri-silvo pastoral systems, charcoal making and cutting for firewood, tree felling and sawing for timber, mineral prospecting, excisions, political ignorance and bad decision-making), unreliable and erratic rainfall, floods and wild fires have "awaken" many political leaders and governments from their want-on destruction and indecisiveness.

In Kenya, the new wave of afforestation initiatives is farmer led. Unlike the afforestation drives of the yester years which were donor initiated and funded (e.g. the World Bank in the 70s), current initiatives are spearheaded by farmers (Kingiri et al. 2008c) who are disappointed with the government's indecision but who have also realized the real possibility of making money from tree growing while at the same time satisfying their own local needs for fuel wood, construction poles from their farms (Jagger \& Pender 2003; Kirongo 2005; Kingiri et al. 2008a).

Technological advances (breeding for improved growth and disease resistance, better management and biotechnology) mean that farmers today are planting improved and better propagules than a few decades ago with better yields (Kirongo et al. 2008). Advances in computing and forestry science in Kenya also imply that relevant and applicable tools e.g. Decision Support Systems (DSS) can be developed which farmers can readily adopt and use. Thus tree growers today can make informed decisions, on what tree species to plant and the possible products-mix needed by markets (poles, charcoal, and timber) and the economic feasibility of the investments. In fact, in a study of farmer perceptions towards tree growing and profitability in the Western region of Kenya, Senelwa et al. (2008b) found that more farmers were slowly shifting from wheat and maize growing in favour of tree growing as they made more money from tree growing (Senelwa et al. 2008 a,b) and it was less demanding. 
But for tree planting to be successful, correct species-site matching is paramount to ensure that the environmental factors at the site are amenable to growth and productivity (Ryan et al. 2010). In many developing nations there is pressure for fertile land to grow food crops to feed the ever growing population. Thus in most cases only arid and semiarid lands are available for tree growing. Eucalyptus, therefore, fits the bill as it grows well in harsh environments (Jagger \& Bender 2003). Moreover, eucalyptus have fast growth rates and high productivity (Dale et al. 2013) factors which make the genus favourable for short rotation forestry. In this paper we explore the eucalyptus profitability (costbenefit analyses) of growing introduced hybrid clones on a five-year rotation for production of poles at the Kenyan Coast. In particular, we look at 2 scenarios; 1) growing improved eucalyptus hybrids on a 5-year rotation, and 2) growing the hybrids for small poles in two rotations; one of 2.5 years and another 2.5 year rotation on coppice.

\section{Methods}

As much as 12 hybrid clones and 3 land races (Table 1) were introduced from South Africa by Mondi (a forestry company in South Africa). The clones were raised at the Tree Biotechnology Project (TBP) in Karura, Nairobi until they were of plantable size. They were then transported by lorry to the Coast (Gede, Sokoke, and Msambweni) during the start of the long rains of 2002 for planting. The three planting sites are found in the Coast Province of Kenya; i.e. Gede and Sokoke in the North Coast and Msambweni in the South Coast.

Site description The experiments were established in Gede and Sokoke in the North Coast and Msambweni in the South Coast (more information summarized in Table 2). The Gede site was under fallow following a maize crop the previous year. The site had been planted with Casuarina equisetifolia which had been harvested about 2 years before planting the clones. The maize had been grown after the casuarina had been harvested. Site preparation involved clearing overgrown bushes and grass before pitting and planting. Sokoke site was a "virgin" forest with Cynometra webberi, which was cleared and the debris burnt before planting while Msambweni site was under grass before planting. The grass was slashed, heaped and burnt before pitting (Kirongo et al. 2010; 2013). Description of individual sites follows in the following sections.

Gede site description The study was set up $500 \mathrm{~m}$ from the main Mombasa-Malindi road at the Kenya Forestry Research Institute (KEFRI) Coastal Regional Research Centre at Gede. The trees were planted in June 2002 during the long rainy season. Gede is located at the Coast of Kenya in Malindi County. The Research Centre is about $20 \mathrm{~km}$ from Malindi and $2 \mathrm{~km}$ from the Watamu junction. The temperatures average $32{ }^{\circ} \mathrm{C}$ and rainfall is bimodal with most rains falling in May-July and short rains in OctoberNovember. The mean annual rainfall is $940 \mathrm{~mm}$. The main dry season is usually from December to March and sometimes extends into April. The soils are mostly light sandy soils devoid of organic matter. Machua and Lelon (2004) reported that soils in many parts of the region, and especially light sandy soils tended to lack enough nitrogen and organic matter which are important for crop growth (Kirongo et al. 2010; 2013).

Sokoke Site description The Sokoke study site is in the North Coast and is located $25 \mathrm{~km}$ from Kilifi town on the main Mombasa-Malindi road. Planting was done in June

Table 1 Location, rainfall, temperatures, altitude, and soils of the sites (Kirongo et al. 2010)

\begin{tabular}{|c|c|c|c|c|c|}
\hline Site & Geo references & $\begin{array}{c}\text { Mean Rainfall } \\
(\mathrm{mm})\end{array}$ & $\begin{array}{c}\text { Mean } \\
\text { temperatures }\left({ }^{\circ} \mathrm{C}\right)\end{array}$ & $\begin{array}{l}\text { Altitude } \\
(\mathrm{m})\end{array}$ & Soils \\
\hline Gede & $\mathrm{S} 3^{\circ} 12^{\prime}$ and $\mathrm{E} 40^{\circ} 02^{\prime}$ & 940 & 32 & 13 & $\begin{array}{l}\text { Orthic feralsols, sandy to sandy- } \\
\text { clay-loams, well drained deep and } \\
\text { very friable. }\end{array}$ \\
\hline Sokoke & $\mathrm{E} 10^{\circ} 59^{\prime}$ and $\mathrm{N} 96^{\circ} 14^{\prime}$ & 700 & 30 & 325 & $\begin{array}{l}\text { Acrid to Rhodic ferralsols, well } \\
\text { drained, deep clay-clay loams, } \\
\text { red to dusky red in colour }\end{array}$ \\
\hline Msambweni & E 59 and N95 & 1,200 & 32 & 10 & $\begin{array}{l}\text { Lithosols with ferralic combisols, } \\
\text { lithic phase. Dark reddish brown } \\
\text { sandy clay loams, well drained but } \\
\text { shallow in some areas. }\end{array}$ \\
\hline
\end{tabular}

Table 2 List of hybrid clones and local land races used in the experiments

\begin{tabular}{lll}
\hline \multicolumn{1}{c}{ Names } & \multicolumn{1}{c}{ Remarks } \\
\hline Hybrid clones & GCs $=14,167,514,540,581$, & GC = grandis-camaldulensis hybrid \\
$584,784,785,796$ & \\
GUs $=7,8,21$ & GU = grandis-urophylla hybrid \\
\hline Local land races & EC, ET, EU & $\begin{array}{l}\text { Local land races }=\text { E. camaldulensis, } \\
\text { E. tereticornis, and } \text { E. urophylla }\end{array}$ \\
\hline
\end{tabular}


2003 during the long rains 2 weeks after planting was completed at the Gede site. The delay was to allow enough moisture build up in Sokoke where the rains were a little late compared to Gede during this particular year. The temperatures in Sokoke average $30^{\circ} \mathrm{C}$ and rainfall is bimodal with the long rains experienced in the period May-July and short rains in October-November. Sokoke is drier than Gede with rainfall averaging $700 \mathrm{~mm}$ per annum. The main dry season is usually from December to March. The soils are mostly deep clay-clay loams with some organic matter (Kirongo et al.2010). This is in part due to the fact that the site had been under natural forest previously before the establishment of this trial.

Msambweni site description The Msambweni study site was located in the South Coast. It was $200 \mathrm{~m}$ from the main Mombasa-Tanga (Tanzania) highway. In this site, planting was also done in June 2003 during the long rains. The average temperatures are $32{ }^{\circ} \mathrm{C}$. Rainfall is bimodal; May-July being the main rain season and short rains being experienced from October to November. Mean annual rainfall is $1,200 \mathrm{~mm}$ which is much higher than for Gede and Sokoke sites in the north Coast. The main dry season is usually from December to March and sometimes may extend into April. The soils are well drained sandy clay loams (Kirongo et al. 2010).

Experimental design and layout The experimental design was Randomized Complete Block Design in all 3 sites. However, the number of replications varied from one site to the other. This was mainly due to the number of seedlings which were available for planting as well as the area (acreage) of land available to set up the experiments. In Gede the trial had 3 replications. In Sokoke the trial was replicated 2 times, while in Msambweni there were 4 replications. The plot sizes in all sites were of equal areas i.e. of 16 trees spaced at $2.5 \times 2.5 \mathrm{~m}$, in a $4 \times 4$ arrangement (Kirongo et al. 2010).

Germplasm used in the study Twelve ecalyptus hybrid clones; 9 GCs (grandis-camaldulensis hybrid) and 3 GUs (grandis-urophylla hybrid) and 3 local races (E. camaldulensis, E. tereticornis and E. urophylla) (Table 2) were used in this study (Kirongo et al. 2010).

Planting and management of trials The experiments were established by the Tree Biotechnology staff in collaboration with the Forest Department (now Kenya Forest Service; KFS). However, the trials were later handed over to KEFRI for management and assessment in November 2002 when the trials were 6 months old. After site preparation, all the sites were to be planted within a range of 4 days at the end of May-beginning of June 2002 (between May $28^{\text {th }}$ and $1^{\text {st }}$ June 2002). However, there were delays of upto to 2 weeks from site to site due to delays in rainfall. The plots were fenced off following planting to keep off small game and other intruders. Huge signs were posted showing the design and clones used in the trials. Hydrogel was added ( 2 table spoons) at the base of the planting holes to increase water retention in the root zone. A termitecide was also added to wad off termites. Weeding was done whenever grass threatened to overtop the planted seedlings (Kirongo \& Muchiri 2009;
Kirongo et al.2010).

Tree growth data Tree height size (ht) in meters (m) and survival counts were assessed 6 months after planting and annually thereafter, while diameter at breast height i.e. at 1.3 $m$ above ground $(\mathrm{dbh})$ in centimeters $(\mathrm{cm})$ was assessed from year 2 onwards (Kirongo \& Muchiri 2009; Kirongo et al. 2010). The data were keyed into Microsoft Excel (Microsoft Office 2007). Analysis of variance (ANOVA) tests were done for each site to identify any significant tree size differences (height and dbh at $p<0.05$ ) among clones and/or blocking effects using PROC GLM in SAS (SAS 2000). Where the overall model was significant, tests for significance between treatments were carried out using the type III SS (sum of squares). Separation of means using the Waller-Duncan Kratio T-Test procedure in SAS was thereafter carried to identify which clones differed significantly $(p<0.05)$ from the others. Standard errors of the means were also calculated (Kirongo \& Muchiri 2009). The best clone was then used for the profitability analyses which are the main theme of this paper. The use of the best performing clone for profitability analyses was based on the premise that farmers and tree grower will normally invest in the best species.

Tree survival Tree survival data was also sourced from the 3 trials established in Gede, Sokoke, and Msambweni by counting the number of individuals surviving at every assessment period. The survival data was arcsine transformed to normalize the variance following which analysis of variance was undertaken. This was already reported in Kirongo and Muchiri (2009).

Tree growth and yield models Tree growth data was modeled using SAS (SAS 2002) to give average tree sizes to use in calculating revenues. The modelling procedures are described in detail by Kirongo and Muchiri (2009). In this paper we use one representative (best) hybrid clone (GC167) tree size data to calculate the expected returns. Our assumption is that most farmers involved in tree growing will plant the better growing hybrids which also show higher survivals.

Investment cost and sell price data As much as 15 farmers from 12 villages in Malindi (see Appendix) who were growing trees were interviewed to ascertain the costs of establishment and management of tree woodlots (Kirongo 2007). Costs were compounded to 5 years (scenario 1) and 2.5 years followed by another 2.5 years under coppice (scenario 2) to evaluate whether the ventures were economically viable. A market survey was carried out in Malindi and Mtwapa near Mombasa to get the buying prices of poles supplied by farmers to hardware shop owners. The prices were most often skewed to lower values as some brokers and middlemen sometimes bought poles from farmers at very low prices. The prices used in this study were those paid by the hardware owners. Marketing information as well as establishment cost data were sourced using questionnaires and personal interviews of farmers as well as some market outlet owners for selling poles in Malindi, Mtwapa, Bombolulu, and Ukunda in Mombasa. Selling 
prices of various sized poles were established for both "good" and "poor" demand scenarios. Good demand scenario was when the prices were very high while poor demand scenario was when the prices were very poor due to either too many poles in the market or too low farm-gate prices as in cases when Middlemen and brokers bought the poles from the farmers. Data management and manipulation (graphs) was achieved using Micro-soft X-cel (Ms Office 2007).

\section{Results and Discussion}

Tree growth and survival Trees grew faster in Gede and Sokoke compared to Msambweni (Table 3), (Kirongo \& Muchiri 2009; Kirongo et al. 2010). The survivals of the best performing clones were similar in all 3 sites, however, the survival of landraces was dismal in Sokoke (Table 3). This shows that the hybrid clones had been site-matched well and/or had adapted well to the sites (Wamalwa et al. 2007).

Clones grew better in all 3 sites as reported by Kirongo and Muchiri (2009) and Kirongo et al. (2010). GC 167 was used for the profitability analyses reported in this paper as it performed very well in all sites (Kirongo \& Muchiri 2009, Kirongo et al.2010).

Investment cost and sell prices of poles The results showed that average initial land preparation costs and establishment costs were similar for the 3 study sites i.e. Gede, Sokoke and Msambweni (Table 4).

Prices for poles were similar in all 3 districts (with minimal fluctuations due to local changes in demand and middlemen manipulations) implying that marketing information was well shared between dealers in north coast and south coast. The market survey in Mombasa (Bombolulu, Mtwapa, and Ukunda) showed prices to be governed by pole straightness and thickness. On average, the price was Kshs.100.00 (about USD1.25) per $2.5 \mathrm{~cm}$ thickness (1 inch), about $25 \%$ less for poor form or short poles. A $15 \mathrm{~cm}$ (6 inches) thick pole sold for an average Kshs.600.00 (USD7.5). Prices were not fixed but sensitive to demand and volumes sought and bargaining power of a buyer. Meanwhile, prices were lowest during low tourist seasons especially when there were no hotel renovations or new constructions going on. During this time prices could fall as low as $50 \%$, thus making a $2.5 \mathrm{~cm}$ dbh pole to sell for Kshs.50.00 (USD0.625) only while a $15 \mathrm{~cm}$ pole for Ksh.300.00 (USD3.75). An economic appraisal was carried out with the results as shown in Table 4.

\section{Cost benefit analyses}

Scenario 1: Poles sold at 2.5 years for scaffolding works and small sized poles From the results, a farmer growing 1 ha of poles for sale after 5 years made Ksh.782,000.00 (USD9,775) under good market demand. This figure reduced to Ksh.302,000.00 (USD3,775) under poor market conditions. The average annual worth of the investment was Ksh.156,000.00 (USD1,950) under good market environment and Ksh.60,000.00 (USD750) under poor market conditions (Table 5). Farmers in Msambweni got lower incomes due to the fact that trees in Msambweni were much smaller after 5 years compared to those in the other 2 areas (Table 2).

Scenario 2: Poles sold at 2.5 years for scaffolding works and small sized poles If a farmer decided to sell the produce at age 2.5 , then only small sized poles for scaffolding would be got (Plate 1). For the sell of material at age 2.5 years, a pole of $10 \mathrm{~m}$ length will have the top $3 \mathrm{~m}$ removed and the remaining $7 \mathrm{~m}$ can be used for small sized poles. In this category, trees had to have a minimum dbh of $7.5 \mathrm{~cm}$ (3 inches). From the results trees in Msambweni were still too thin and small for the market (Table 6). No report of use of small end diameters for fuelwood were recorded by the interviewees.

A farmer who sold poles at mid-rotation (2.5 years) for small sized poles in Malindi and Sokoke made a net profit of Kshs.275,000(USD3,437.5) when the market was very good and Kshs.75,000 (USD937.5) when the market was bad. It is therefore advisable for farmers to keep the trees longer when

Table 3 Average tree sizes and mean survival at 5 years of age in Gede, Sokoke, and Msambweni (Kirongo \& Muchiri 2009)

\begin{tabular}{llcccc}
\hline Type & \multicolumn{2}{c}{ Gede } & \multicolumn{2}{c}{ Sokoke } & Msambweni \\
\cline { 2 - 6 } & \multicolumn{1}{c}{$\begin{array}{c}\text { Mean height } \\
(\mathrm{m})\end{array}$} & $\begin{array}{c}\text { Mean dbh } \\
(\mathrm{cm})\end{array}$ & $\begin{array}{c}\text { Mean height } \\
(\mathrm{m})\end{array}$ & $\begin{array}{c}\text { Mean height } \\
(\mathrm{cm})\end{array}$ & $\begin{array}{c}\text { Mean dbh } \\
(\mathrm{cm})\end{array}$ \\
\hline Best clone & 18.9 & 14.8 & 18.1 & 12.8 & 14.0 \\
Survival & Over 90\% & & Over $90 \%$ & Over $90 \%$ \\
Land race & 14.8 & 11.1 & 15.7 & 12.0 & 9.5 \\
Survival & Over 70\% & & $20 \%$ & & 8.7 \\
\hline
\end{tabular}

Table 4 Initial investment costs (land rent, land preparation, stock, and planting) based on 1 ha

\begin{tabular}{|c|c|c|c|c|c|}
\hline $\begin{array}{l}\text { Annual land rent } \\
\qquad\left(\mathrm{Kshs} \mathrm{ha}^{-1}\right)\end{array}$ & $\begin{array}{l}\text { Land preparation } \\
\left(\mathrm{Kshs} \mathrm{ha}^{-1}\right)\end{array}$ & $\begin{array}{l}\text { Seedlings cost } \\
\left(\mathrm{Kshs} \mathrm{ha}^{-1}\right)\end{array}$ & $\begin{array}{l}\text { Actual planting } \\
\left(\mathrm{Kshs} \mathrm{ha}^{-1}\right)\end{array}$ & $\begin{array}{c}\text { Annual } \\
\text { maintenance } \\
\left(\text { Kshs ha }^{-1}\right) \\
\end{array}$ & $\begin{array}{c}\text { Average initial } \\
\text { investment costs } \\
\left.(\mathrm{Kshs} \mathrm{ha})^{-1}\right)\end{array}$ \\
\hline 4,500 & 8,500 & $41,250 *$ & 5,000 & 7,500 & 66,750 \\
\hline
\end{tabular}

*Planting at $2 \times 2 \mathrm{~m} ; 10 \%$ more seedlings to cater for losses, beating up/blanking gives 2,750 seedlings purchased at Ksh.15.00 
Table 5 Economic appraisal of a 5-year forestry venture with eucalyptus with no intermediate returns

\begin{tabular}{|c|c|c|c|c|c|}
\hline \multirow{2}{*}{ Activity } & \multicolumn{5}{|c|}{ Years } \\
\hline & 1 & 2 & 3 & 4 & 5 \\
\hline Land rent $\left(\mathrm{ha}^{-1}\right)$ & $4,500.00$ & $4,500.00$ & $4,500.00$ & $4,500.00$ & $4,500.00$ \\
\hline Land preparation $\left(\mathrm{ha}^{-1}\right)$ & $8,500.00$ & & & & \\
\hline Planting stock & $41,250.00$ & & & & \\
\hline Planting (hole digging and planting) & $5,000.00$ & & & & \\
\hline $\begin{array}{l}\text { Management (weeding, hygiene } \\
\text { diseases treatment) }\end{array}$ & $7,500.00$ & $7,500.00$ & $7,500.00$ & $7,500.00$ & $7,500.00$ \\
\hline $\begin{array}{l}\text { Professional services ( } 4 \text { forester } \\
\text { visits) }\end{array}$ & $4,000.00$ & $4,000.00$ & $4,000.00$ & $4,000.00$ & $4,000.00$ \\
\hline \multicolumn{6}{|l|}{ Other overheads } \\
\hline Total cost & $70,750.00$ & $16,000.00$ & $16,000.00$ & $16,000.00$ & $16.000,00$ \\
\hline \multirow[t]{2}{*}{ Present value $(r=10 \%)$} & $113,943.58$ & $23,425.60$ & $21.296,00$ & $19.360,00$ & $17.600,00$ \\
\hline & $\begin{array}{l}\text { Best case } \\
\text { scenario }\end{array}$ & & $\begin{array}{l}\text { Worst case } \\
\text { scenario }\end{array}$ & & \\
\hline Total compounded cost & $178,025.18$ & & $178,025.18$ & & \\
\hline Total income after sell & - & & 0.00 & & \\
\hline Difference & $(178,025.18) \mathrm{ha}^{-1}$ & & $(178,025.18)$ & & \\
\hline Average annual worth of investement & $(35,605.04) \mathrm{ha}^{-1}$ & & $(35,605.04)$ & & \\
\hline
\end{tabular}

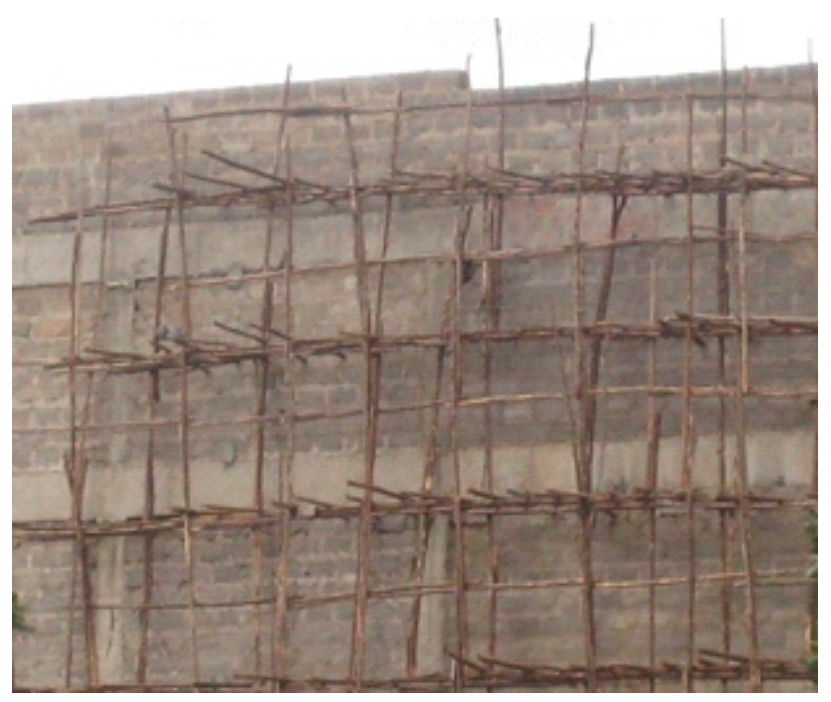

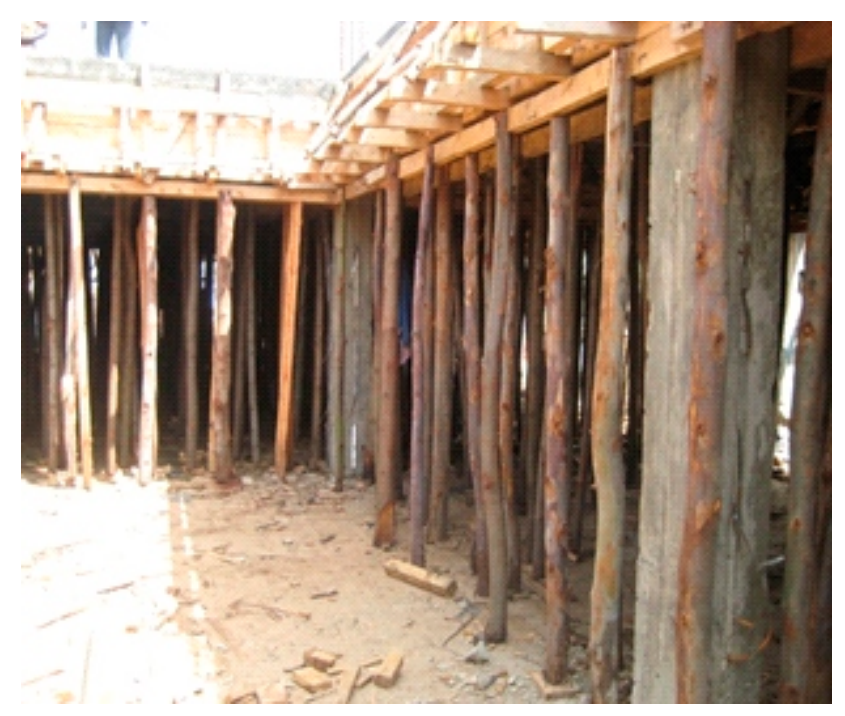

b

Plate 1 Two types of scaffolding commonly used in buildings. Type 1 (a) can use thin and longer poles while type 2 (b) will need thicker, shortter and stronger material.

Table 6 Average tree sizes after 2 years

\begin{tabular}{lcccccc}
\hline Type & \multicolumn{2}{c}{ Gede } & \multicolumn{2}{c}{ Sokoke } & \multicolumn{2}{c}{ Msambweni } \\
& $\begin{array}{c}\text { Mean height } \\
(\mathrm{m})\end{array}$ & $\begin{array}{c}\text { Mean dbh } \\
(\mathrm{cm})\end{array}$ & $\begin{array}{c}\text { Mean height } \\
(\mathrm{m})\end{array}$ & $\begin{array}{c}\text { Mean dbh } \\
(\mathrm{cm})\end{array}$ & $\begin{array}{c}\text { Mean height } \\
(\mathrm{m})\end{array}$ & $\begin{array}{c}\text { Mean dbh } \\
(\mathrm{cm})\end{array}$ \\
\hline Best clone & 11.1 & 7.7 & 9.3 & 7.4 & 5.4 & 3.8 \\
Land race & 8.3 & 6.3 & 9 & 6.9 & 4.6 & 3.8 \\
\hline
\end{tabular}


the market is not favourable. This is because keeping the trees upto age 5 years will have a resultant net income growth on investment (Figure 1). Marketing season greatly influenced the net incomes as well as the duration of the investment (Figure 1 and Figure 2).

A third scenario was investigated where costs were doubled to reflect the hard economic times as are being faced in many parts of the world. The results showed that even if the cost of wages was doubled farmers would still make net incomes of Kshs.670,000.00 (USD8,375) (good market) and Kshs.190,000.00 (USD2,375) (poor markets) at the end of 5 years (Table 7; Figure 3 ).

From the results it was evident that investing in tree growing was a profitable venture. Given the current unassailable energy costs it may be possible to sell firewood or charcoal. However, this option needs further research and enabling policy support (e.g. recommendations by

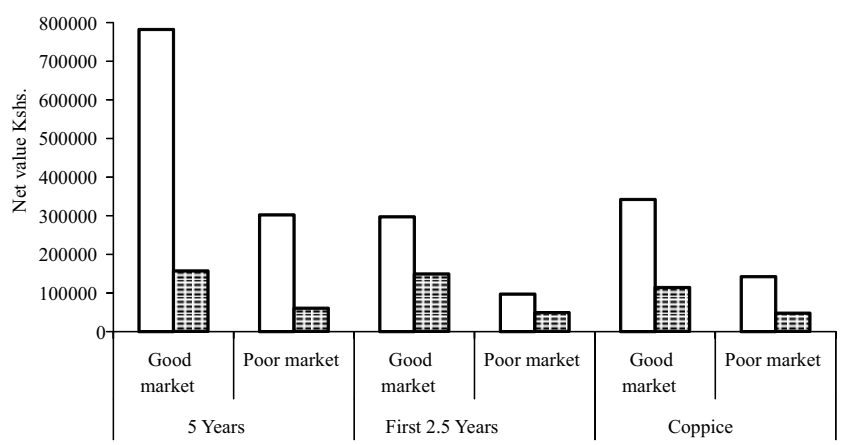

Figure 1 Total Net incomes and annual net Income growth on investment during good and poor markets scenarios. Total net income ( $\square)$, Annual net growth (田).
Sustainable Energy Africa 2006) to ensure that charcoal from trees grown on-farm is encouraged and that it fetches a premium compared to that from trees cut illegally from woodlands. Other studies elsewhere (e.g. Ubukata et al. 1998; Sands et al.; 1999; Jagger \& Pender 2003) have also reported eucalyptus growing on farms by peasant farmers to be highly profitable. But it is worth noting also that farmers need to get professional guidance especially as regards correct species/genotype selection and management, in particular spacing. For example, in a study of genotype and spacing effects on eucalypts growth, Kirongo et al. (2012) report reduced growth for some genotypes and for closely spaced trees. Meanwhile, in another study, Kirongo et al. (2013) reported that many farmers risked significant losses in investment arising from significant tree deaths as a result of intra-specific competition (between similar species) if trees were too crowded and recommended that farmers be advised

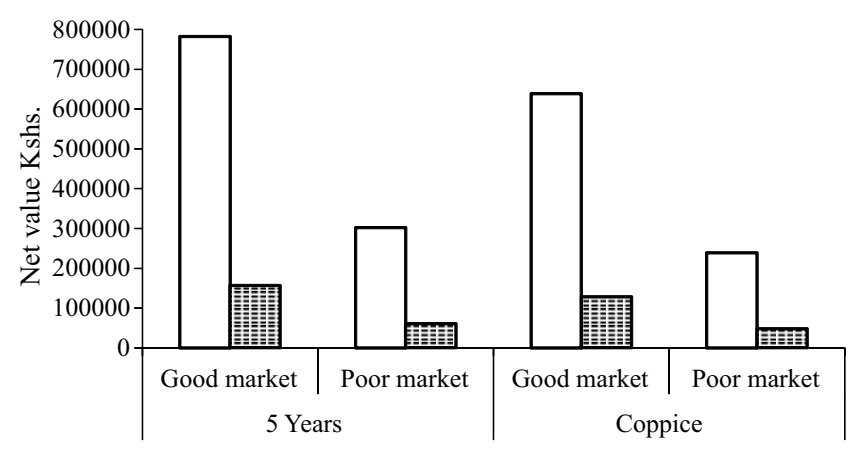

Figure 2 Total Net incomes and annual net Income growth on investment during 5 years under continuous and coppice scenarios. Total net income ( $\square)$, Annual net growth (田).

Table 7 Economic appraisal of a 5-year forestry venture with eucalyptus with no intermediate returns but under stringent economic scenario (doubled wages, land rent and management costs)

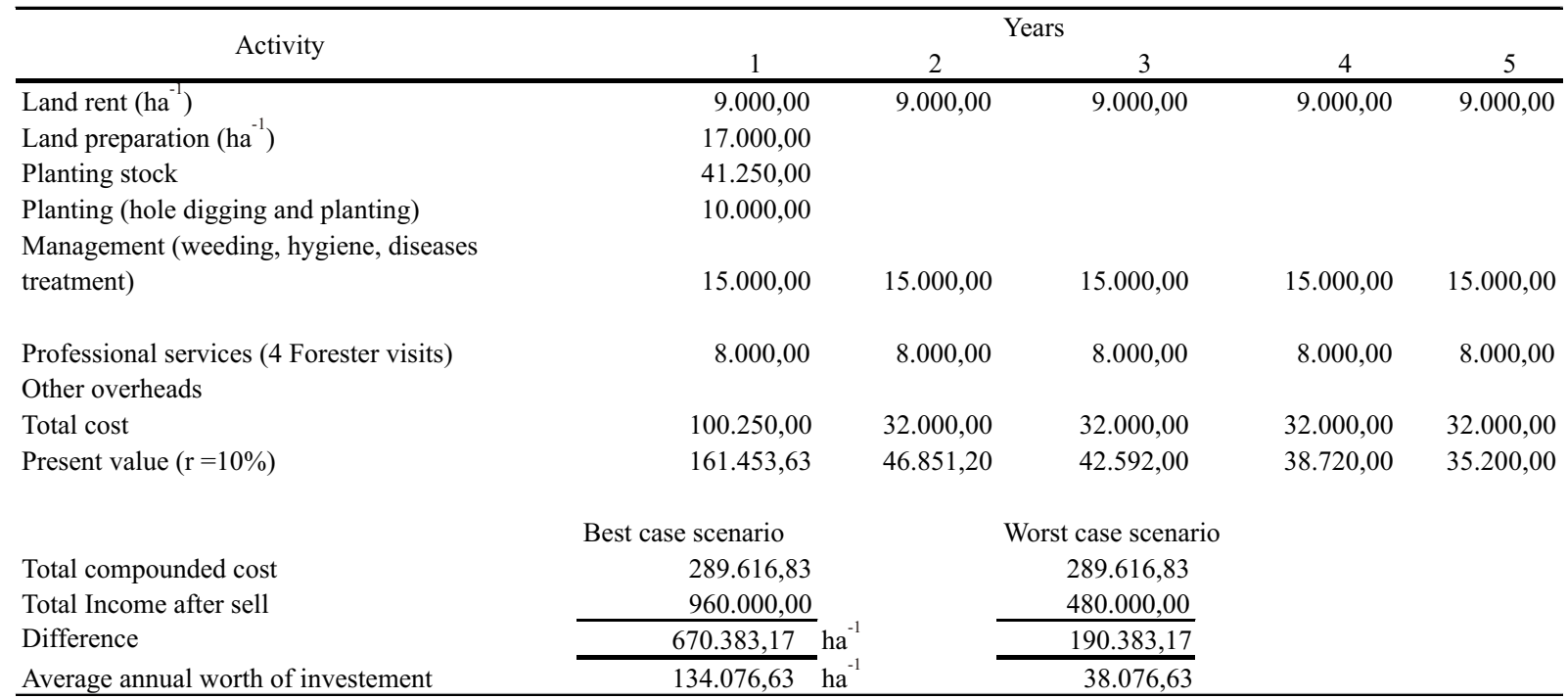




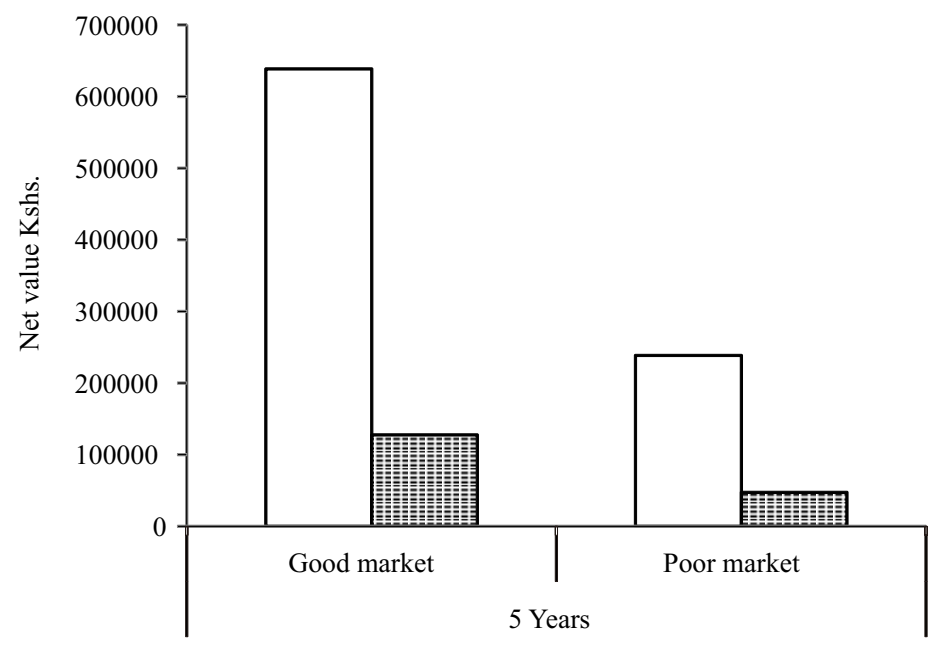

Figure 3 Total net incomes and annual net income growth on investment during 5 years under stringent economic scenarios (doubled wages, land rent, and management costs).

not to plant trees on their farms too closely. In addition sound policies are a corner stone to encourage peasant farmers to invest in tree growing (Fumikazu 2001).

Implications on Kenyan forestry Our findings support previous studies in other parts of Kenya (Kingiri et al. 2008b) which showed tree growing to be a very profitable venture. In fact in their study, Kingiri et al. (2008b) showed clearly that the returns from tree growing far outweighed those from maize growing, wheat growing and sugarcane growing. Their study had a lot of credence given that it was conducted in a wide area covering Uasin Gishu, Western, and Nyanza regions of Kenya. Further, our findings have shown clearly that it is possible to employ workers to tend short rotation crops (refer to example in this paper) and still break even. The findings have serious implications on land use as well as food security in Kenya as farmers disgruntled with high input costs of Agriculture may turn to forestry with dire consequences to food production.

However, the move by some farmers to grow trees has had very good impact on the tree cover in the country with many counties showing increased tree cover on farmlands. This is a move welcomed by many foresters who see their unceasing efforts to encourage farmers to plant trees on farm as bearing fruit. This move, is also seen to have positive effect on the environmental wellbeing of the country especially regarding GHGs effects and $\mathrm{C}$-sequestration. Further research on possibilities of the Kenya Forest Service getting loans to tend plantations (by contracting or employing communities near forests) may be worthwhile.

\section{Conclusion}

Based on the results from this study we draw the following 2 main conclusions: 1) that the growing of eucalyptus hybrid clones is a profitable undertaking and 2) that farmers who undertake eucalyptus growing at the Coast are better advised to grow the trees on 5-year rotations, especially when the market is not favourable

\section{Acknowledgements}

The writers are sincerely grateful to all the staff of KEFRI Gede Region Research Center. In particular the enumerators for taking all the measurements efficiently. We acknowledge support from the Center Scientists and foresters who supervised the work. We extend our thanks to KFS (the then Forest Department), the Tree Biotechnology Programme of Karura for providing the clones and Mondi forest company of South Africa for the worthwhile collaboration. We are highly indebted to the farmers who took part in the surveys to get the costs for planting, weeding and management. The owners of the market outlets in Malindi, Mtwapa, Bombulul and Ukunda are thanked for providing market data. Finally we appreciate the logistical support from KEFRI and the University of Eldoret during the work and during the writing of this paper.

\section{References}

Dale VH, Langholtz MH, Wesh BM, Eaton LM. 2013. Environmental and Socioeconomic indicators for Bioenergy sustainability as applied to Eucalyptus. International Journal of Forestry Research. 2013:110. http://dx.doi.org/10.1155/2013/215276.

Kirongo BB. 2005. The proceedings of the workshop on "Using Farm Forestry as a vehicle to back roll poverty, better the environment and change landscapes" held at the Eden Roc Hotel, Malindi, (Kenya) on the $11^{\text {th }}-12^{\text {th }}$ August 2005 (pp. 37).

Kirongo BB. 2007. Cost of Establishing Tree Woodlots by Farmers in Malindi. Kenya: KEFRI Gede Regional Research Center Reports. 
Kirongo BB, Muchiri MN. 2009. Modelling early growth of Eucalyptus hybrid clones at the Kenyan Coast. Journal of East African Natural Resources Management. 13: 257-271.

Kirongo BB, Kimani GK, Senelwa K, Mbelase A, Mbae M. 2010. Five year growth and survival of Eucalyptus hybrid clones in Coastal Kenya. Jurnal Manajemen Hutan Tropika 16(1): 1-9.

Kirongo BB, Mbelase AS, Senelwa K, Hitimana J, Etiégni L. 2012. Spacing and genotype on height and diameter growth of four eucalyptus under short rotation. Jurnal Manajemen Hutan Tropika 18 (1):1-9. http://dx.doi. org/10.7226/jtfm.18.1.1.

Kirongo BB, Christine K, Kimani GK. 2013. The effects of Intra-specific competition on survival in a Casuarina equisetifolia spacing trial in Gede, Malindi, Kenya. E3 Journal of Environmental Research and Management 4(7):293-298.

Otávio C et al. 2013. Stem production, light absorption and light use efficiency between dominant and nondominant trees of Eucalyptus grandis across a productivity gradient in Brazil. Forest Ecology and Management 288:14-20. http://dx.doi.org/10.1016/ j.foreco.2012.07.035.

Sands PJ, Rawlins W, Battglia M. 1999. Use of a simple plantation productivity model to study the profitability of irrigatd Eucalyptus globulus. Ecological Modelling 117:125-141. http://dx.doi. org/10.1016/S0304-3800(99)00021-6.

Saumu N. 2007. BSc. Dessertation report. Moi University.

Senelwa K et al. 2008a. Comparisons of returns from Wheat, Maize and tree growing in Western Kenya. Kenya: Moi University Conference Eldoret.

Senelwa K et al. 2008b. Cost Benefit Analysis of Producing
Transmission Poles. Proceedings: $1^{s t}$ National Conference of Commercial Tree Growing. Kenyatta International Conference Center. $21^{\text {st }}$ Nov. 2008.

Senelwa K et al. 2008c. Feasibility and Opportunities for Tree Out-Grower Schemes in Kenya. Proceedings of the $3^{\text {rd }}$ Conference of the Forestry Society of Kenya (FSK). Sun Set Hotel, Kisumu, Kenya. $28^{\text {th }}$ September- $1^{\text {st }}$ October 2008.

Senelwa K, Etiegni L, Osano O, Kirongo BK. 2012. Environmental Impacts of Biofuel Production in Africa. Book Chapter. In: Bioenergy for Sustainable Development in Africa. Rainer J, Dominik R, editors. Springer Verlag, Munich, Germany. http://dx.doi.org/10.1007/978-94-007-2181-4 20.

Ubukata F, Takeda S, Watanabeh H, Jamroenprucksa M. 1998. The profitability of Eucalyptus farm forest in Northeast Thailand. Forest Research 70:35-42.

Ubukata F. 2001. The expansion of eucalyptus farm forest and its socioeconomic background: a case study of two villages in Khon Kaen Province, Northeast Thailand. Southeast Asian Studies 39(3):417-436.

Jagger P, Pender J. 2003. The role of trees for sustainable managemet of less-favoured lands: the case of eucalyptus in Ethiopia. Forest Policy and Economics 5(1):83-95. http://dx.doi.org/10.1016/S1389-9341 (01)00078-8

Ryan MG et al. 2010. Factors controlling eucalyptus productivity: How water availability and stand structure alter production and carbon allocation. Forest Ecology and Management 259(9):1695-1703. http://dx.doi.org/10.1016/j.foreco.2010.01.013.

Wamalwa L, Chagala-Odera E, Oeba V, Oballa P. 2007. Adaptability of 4 year old eucalyptus species and clones in Kenya. Discovery and Innovation Journal 19(4): 326-334 